\title{
NATIONAL SECURITY AND THE PERMIT FOR ACCESS TO CLASSIFIED INFORMATION -SOCIAL AND LEGAL ASPECTS IN THE EVENT OF A DENIAL OF REVOCATION OF A PERMIT FOR ACCESS TO CLASSIFIED INFORMATION.
}

\author{
Stoimen BARDAROV \\ “Neofit Rilski” South-West University,Blagoevgrad, Bulgaria \\ stoimen.bardarov@gmail.com
}

\begin{abstract}
This study examines the lack of legal possibility for defence in the event of a Denial of Revocation of a permit for access to classified information. The analysis of the research is focused on the appeal procedure before the Supreme Administrative Court of Bulgaria and the possibilities for conducting an internal inquiry into the conformity with the law of the Denial or Revocation ad hoc within the appeal and/or cassation procedures before the Supreme Administrative Court.
\end{abstract}

Keywords: Supreme Administrative Court, permit for access to classified information, appeal and cassation procedures, national security and access to classified information.

\section{Introduction}

The administrative proceedings for obtaining a permit for access to classified information, resp. on its revocation or refusal to issue a permit for access to classified information is arranged in Chapter Five of the Classified Information Protection Act (CIPA)[1]. The State Board of Information Security is the administrative body appointed by the legislator to implement the policy of the Republic of Bulgaria for the protection of classified information. When issuing, refusing to issue or revoking an issued permit for access to classified information, the said authority performs such an act in the conditions of operational independence. That fact makes an important point in the proceedings studied as it is a peculiar limitation with regard to legal control. On the one hand, the administrative legislation currently in force prohibits the Court within the legal proceedings started from checking the expediency of the individual administrative act issued by the administrative body (article 145, paragraph 1 in conjunction with article 146 of the Administrative Procedure Code)[2]. On the other hand, the special law imposes special proceedings for the legal appeal against the revocation of or refusal to issue a permit for access to classified information (article 69 of the CIPA) establishing a three-member panel of the Supreme Administrative Court as the one and only competent judicial body in such cases.

\section{The Law}

The body that has issued the permit for access to classified information in the presence of the situation under article 59 of the CIPA shall revoke this permit issued, if: 1. it is found that the person fails to meet some of the requirements under article 40 paragraph 1 (as amended, State Official Gazette \# 71/2016) [3].

2. the person has violated the law or any secondary legislation on its implementation, 
which has created hazard of occurrence of or has resulted in significant damages of the interest of the state, entities or persons in the area of protection of classified information;

3. the person has systematically violated the law or any secondary legislation related to the protection of classified information.

\section{Legal aspects of the procedure}

The presence of the actual grounds for the occurrence of the prerequisites stipulated in the CIPA is to be established thoroughly and beyond contradiction within the proceedings on revocation, which are analogical to the proceedings for the issue of the individual administrative act (IAA). The lack of evidence by which the surveying body is to reason and this way prove the lawfulness of the resolution for the revocation of an issued permit for access makes itself sufficient grounds for the repeal of the IAA for the revocation of the permit for access to classified information. The estimation of the conformity to law of such actions should be complied with the substantive and procedural law, and any issuance of a IAA for the revocation of the access to classified information (CI) on the grounds of expedience shall be inadmissible.

When the issue is studied in terms of substantive law, the possibility for revocation of a permit due to nonperformance and/or violation of obligations imposed by the CIPA or some other special law and included in the person's job description is to be considered first. The non-performance of the official duties by the part of an information security officer (ISO) could constitute or create a prerequisite for the occurrence of criminal liability only if such non-performance constitutes an infringement, apart from the tort liability for an unauthorized access under article 357 et seq. of the Criminal Code[4]. After Judgment \# 7 from year 2016 was ruled by the Constitutional Court
(State Official Gazette \# 49/2016, repealed State Official Gazette \# 71/2016)[5] the consequences from criminal prosecution within article 40 paragraph 1 p. 5 of the CIPA should be restricted by the general case. The text of the repealed p. 5 of article 40 paragraph 1 of the CIPA was a negative procedural prerequisite for the presence of a Permit for access to CI upon pre-trial or legal proceedings instigated against the person for an intentional general crime.

With the repeal of the provision in question there appeared a legal vacuum concerning the role and legal powers of the prosecutor's office and the security services at the phase of pre-trial proceedings, and in particular what positive admissibility prerequisites should exist in order to rule a refusal of or revocation of a permit for access to CI. The practice after the repeal has outlined trends characterized by a potential for violation of the European Convention on Human Rights (ECHR)[6]. The requirement for the presence of preliminary proceedings introduced formal guarantees for the defense of the rights of the person surveyed. With the repeal of these provisions the person surveyed has no procedural opportunity for defense.

The act of revocation of a permit for access to classified information is issued on the grounds of article 59, paragraph 1, p.2 of the CIPA. The provision of p. 2 of paragraph 1 of article 59 of the CIPA contains seven hypotheses:

1. Committed violation of the law by the part of the person; 2. Committed violation of some secondary legislation on the law implementation by the part of the person; 3 . Bringing to a hazard of the occurrence of significant damages to the interests of the state, entities or individuals in the area of CI protection by the part of the person; 4. Bringing to significant damages to the interests of the state by the part of the person; 5. Damaging the interests of the state in the area of protection of classified information by the part of the person; 6 . 
Damaging the interests of the entities in the area of protection of classified information by the part of the person; 7 . Damaging the interests of the individuals in the area of protection of classified information by the part of the person.

If no particular legal ground is specified out of the several possible ones stipulated by the CIPA, the IAA issued by the State Board of Information Security (SBIS) is null and void. The seven separate, independent and mutually exclusive grounds for the revocation of the permit for access to CI as envisaged by p. 2 of paragraph 1 of article 59 of the CIPA, obligate the competent authority to specify some ground out of the five envisaged on which the revocation was performed. If no such specification is made the act shall be unlawful and subject to repeal because this way the person's interests are infringed and the purpose of the law is not achieved. On the one hand, the right of defense of the person is infringed, and on the other hand, the Supreme Administrative Court (SAC) being the court of jurisdiction cannot estimate which facts and circumstances have been considered and taken into account by the administrative authority when issuing its act. The judicial review is restricted to the issue of the lawfulness of the revocation itself - whether all the facts were available as contained in the hypothesis of the specified ground under the conditions of which the authority has exercised its statutory power to revoke the access to CI.

The act for the revocation of a permit for access to classified information may be null and void if issued by an incompetent authority.

As a rule the authority issuing the respective permit for access to classified information is also the authority that is to revoke it (article 59 of the CIPA). The competence of the administrative authority is defined in general as the circle of issues with resolving of which the authority is assigned by the law together with the means for resolving such issues.

The competence as provided under article 21 and $\S 1$ of the Additional Provisions of the Administrative Procedure Code (APC) is always assigned by the law, and in accordance with the provision of article 173 of the APC the lack of competence always brings to the nullity of the act issued. Within this sense the competence of the SBIS for the revocation of a permit issued to an ISO is legally established.

The lack of competence of the authority that issued the contested act, the non-observance of the established form of the act, material violations of the administrative procedure rules, discrepancy with the substantive law provisions and incompliance with the purpose of the law (article 146 of the APC) are the criteria for the nullity of an issued administrative act. The Court is obliged to check the compliance with the law of the procedure of reliability survey and revocation of the permit of the person surveyed. Such revocation should be issued upon the occurrence of new facts and circumstances that bring to the unreliability of the person in terms of security under article 41 or in terms of keeping the secret under article 42 of the CIPA. Within this sense such new facts and circumstances should have occurred after the issue of the permit and should not have been known to the surveying authority.[7]

\section{The praxis of the European Court of Human Rights}

A revocation ruled by the SBIS is subject to no control and this way citizens' rights guaranteed by the constitution are infringed upon. This is also the sense of the judgment ruled by the court under the case Miryana Petrova vs. Bulgaria (Complaint \# $57148 / 08)$ from the $21^{\text {st }}$ July 2016[8], which became a final one on 21/10/2016 : ,... The Court points out that "the conclusion regarding the applicability of 
article 6 does not concern the issue of how the different guarantees of the same article, for example, the scope of review that is required by the national courts of justice ... is to be applied with regard to disputes concerning civil servants". As one of these guarantees is that the Court hearing the case should be competent to consider all the actual and legal issues of significance for the dispute brought before it (inter alia, judgment, Terra Woningen B.V. v. the Netherlands, the $17^{\text {th }}$ December 1996 , Putter v. Bulgaria, No. 38789/02, etc.), the major issue in this case is whether this requirement is applied equally and without qualification with regard to the disputes related to the issue of permission for access of civil servants. The Court finds that the refusal of the Supreme Administrative Court to conduct an independent inquiry of an issue that is of a material significance for resolving the case of the claimant, and namely his/her mental eligibility for employment with the Ministry of Internal Affairs - constitutes an infringement under article 6 of the Convention.

The claimant is entitled to initiating a lawsuit and demanding revocation of his/her dismissal, reinstatement into position and compensation for lost income. However, in all these cases, it seems that the courts did not deal with establishing if grounds for the refusal of a permit for access existed, although such a refusal makes the dismissal inevitable. The conclusion of the courts that they are bound by the official refusal for the provision of access to classified information, and that they cannot subject it to review in any way whatsoever, is in compliance with the applicable national legislation. The European Court of Human Rights on its part finds that in its exclusive reference to such a refusal in the case of the claimant Petrova, the national courts of justice have refuses to inquire independently an issue which is of a material significance for the judgment in the case, and this way the courts have deprived themselves of the competence to hear the case.

\section{Conclusions:}

The court accepts, in a different aspect though, that legitimate considerations of national security may justify restrictions of the rights listed in article $6 \$ 1$ of the Convention, but it also concludes that they should not prevent the official consideration upon their merits of the claimants' complaints, this way constituting a nonproportional restriction of their right of access to court. ( Tinnelly and Son Ltd and Others and McElduff and Others v. the United Kingdom, 10.07.1998, Devenney v. The United Kingdom, №24265/94).

Such a revocation of a permit for access to classified information is just a prerequisite for a future incapability to perform one's duties at work. As of the day of termination of the employment relation no event has occurred that has brought to the incapability to perform one's duties.

The Court establishes that in the case of Miryana Petrova v. Bulgaria the courts of justice have refused to review the substantive law reasons that underlie the refusal for granting a permit for access and that its final character has the effect of a prevention of legal resolving under their merits of the claimant's complaints. Notwithstanding that, neither the judgments of the courts of justice in their motives, nor the statements of the Government related to issues concerning the applicability of article 6, have attempted to substantiate such refusal for access to court of appropriate competence with regard to its proportionality to the specified legitimate purpose for defense of the national security. The considerations presented hereinabove are sufficient for the Court to conclude that there is a violation of article $6 \S 1$ of the Convention. They also indicate that the most appropriate form of compensation in the cases where the claimant has no access 
to court in violation of article $6 \S 1$ of the Convention, as a rule, is the timely reopening of the lawsuit and re-hearing of the case in compliance with all the requirements for a fair trial.

\section{References}

[1] Classified Information Protection Act (CIPA) f.pb. State Official Gazzete (SOG) \#45/30.04.2002 1.chg. SOG \#17 23.02.2018 http://www.pz.government.bg/z/11.pdf

[2] Administrative Procedure Code of Republic of Bulgaria 12.07.2006 https://www.lex.bg/laws/ldoc/2135521015

[3] State Official Gazette of Republic of Bulgaria \# 71/13.09/2016 http://dv.parliament.bg/DVWeb/broeveList.faces

[4] Penal Code of Republic of Bulgaria https://lex.bg/bg/laws/ldoc/1589654529

[5] State Official Gazette of Republic of Bulgaria \# 49/28.06/2016 http://dv.parliament.bg/DVWeb/broeveList.faces

[6] European Convention on Human Rights (ECHR) https://www.echr.coe.int/Documents/Convention_ENG.pdf

[7] ECHR 255 (2016) of 21.07.2016 Judgments and decisions https://www.echr.coe.int/Documents/Annual_report_2016_ENG.pdf

[8] Case Miryana Petrova vs. Bulgaria (Complaint \# 57148/08) The European Court of Human Rights http://hudoc.echr.coe.int/eng?i=001-140810 